\title{
Elements of Romanian historical morphology, based on the first Romanian translation of the Septuagint (ms. 45, BAR Cluj)
}

\author{
Ana-Maria Minuț* \\ Faculty of Letters, "Alexandru Ioan Cuza" University, Bd. Carol I 11, 700506 Iaşi, Romania
}

\begin{abstract}
Article info
History:

Received February 1, 2017

Accepted February 2, 2017

Published March 23, 2017

Key words:

Old Romanian literary

language

historical morphology

translation

biblical text

diachrony
\end{abstract}

\begin{abstract}
In the CNCS project titled Prima traducere românească a Septuagintei, operă a lui Nicolae Milescu (Ms. 45 BAR Cluj). Ediție critică, studii lingvisticeșifilologice, we have developed the morphological study of the text. The existence, inside this considerable manuscript (over 900 pages), of a broad and diverse linguistic issue fully justifies the interest in its analysis. In the present study three aspects are pursued: permanent points which ensure the continuity of the morphological system, the innovations (either in early or advanced stages) and the specific elements of the text as such. The detailed study of ms. 45 , based on traditional descriptive methods but with elements from more recent linguistic theories, contributes to the understanding of the historical dynamics of the formation of literary norms at a grammatical level.
\end{abstract}

\section{Introduction}

Representing a revised translation of the Septuagint (Frankfurt edition, 1597) done by Nicolae Milescu in Constantinople, between 1661 and 1664, the text Ms. 45 underlies the first whole scriptural Romanian version, printed in Bucharest in 1688. Beyond the cultural importance of the text and the captivating aspects related to its authorship, the manuscript 45 provides the researchers an extremely rich investigative field. Accepting the idea that "the elements of language include not only a structure characteristic of a particular epoch of language development but of a structure and process built in time" the history of the Romanian language being seen, for this reason, "as a sequence of rules and as coexisting rules of some literary variants" (Frâncu, 2009, p. 17), we intend to pursue three aspects in this study: a) the way the rules of that time are reflected in ms. 45 , at the morphological level, b) the extent to which extreme variations from the norm are recorded and what the status of the morphological changes is, $c$ ) which the specific elements of the text as such are.

\section{Stable elements}

Firstly, we notice some rules of the morphological system specific to the time to which ms. 45 belongs.

\subsection{Nouns}

2.1.1. The plural use (but having a singular meaning) of abstract nouns made with the suffix -ête (< Lat. itiem) such as bătrînêțe, tinerêțe, blîndêțe is a feature of the old language (Frâncu, 2009, p. 29); the singular form occurs more often in the second half of the $18^{\text {th }}$ century. Within ms. 45 , these nouns usually occur with their plural form: și ședzură înaintea lui cel dentîi născut, după bătrînêțele lui, și cel mai tînăr, după tinerêțele lui (Fac, 43, 33), intru tinerêțele-ți n-ai adunat, și cum vei afla întru bătrînêțele-ți? (Sir, 25, 5), frîmsêțele muierilor s-au primenit (1Mac, 1, 27), eu frîmsêțele voastre laud (Iosip, 8,

\footnotetext{
*Email address:a_minut@hotmail.com.
} 
Ana-Maria Minuț

5), pomenêște, Doamne, pre David și toate blîndêțele lui (Ps, 131, 1), cîtu e de înfrîmsețată a căruntêțelor judecată!; mărirea bătrînilor - căruntêțele (Parim, 20, 29), etc.

2.1.2. As in other texts of the time, the preposition $a$ occurs in $\mathrm{ms} .45$ in some constructions equivalent to dative and genitive: ieși-va om den semințiia lui și va stăpîni a limbi multe (Num, 24, 7), a multe limbi domnind (Est, 3, 13), fată a om preut (Lev, 21, 9), fecior a fämei văduă (3Reg, 7, 14), Dumnedzău a munți, Dumnedzăul lui Israil, și nu Dumnedzău a văi! (3Reg, 20, 23), și o astrucați pre ea, căci fată a împărat iaste (4Reg, 9, 34), veseliia a măgari sălbateci, păşciuni a păstori (Is, 32, 14), etc.

2.1.3. The preposition de is selected in genitive in cases such as: suflà întru fața lui suflare de viață (Fac, 2 , 7), vrêmea de prînz iaste (Sus, 1, 12), ne-au scos Domnul den pămîntul Eghiptului, den casă de robime (Ieș, 13, 14), și lăcui împreună muiêrea lui Sampson cu aducătoriul de mireasă lui, carele era tovarăş lui (Jud, 14, 19), intr-o parte de țarina lui (Fac, 23, 9) $)^{1}$.

2.1.4. Constructions with the preposition la equivalent to the dative are common: porincifaraó la oameni (Fac, 12, 20), la aceștia oameni să nu faaceți strîmbătate (Fac, 19, 8), vei lua la ficiorul mieu, Isaac, fämêie de acoló (Fac, 24, 4), el va împărți hrană la boiêri (Fac, 49, 20), au ales să să aducă la împăratul (2Mac, 11, 36). The noun may be preceded by the indefinite adjective tot: porinci Aviméleh la tot nărodul lui (Fac, 26, 11), porînci Faraón la tot nărodul lui (Ieș, 1,22), și dzise David, împăratul, la toată adunarea (1Paral, $29,1)$, etc.

\subsection{Pronouns}

2.2.1. A feature of the old Romanian morphology (Densusianu, 1932, p. 117; Arvinte, 1988, p. 74; Frâncu, 2009, p. 52), fully illustrated by ms. 45, is the massive use of the third person, together with the forms el, ea, ei, iale, and êle, the successors of the popular Latin demonstrative pronouns *illu, illa, illi, ille, of the forms îns / însu / (and especially) însul, însă / însa, înşi / înşii, înse / însele, successors of the

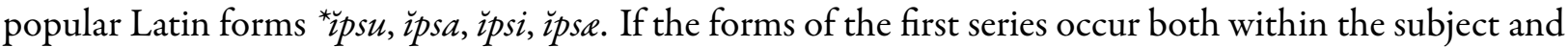
the accusative, the forms of the second series exclusively occur in the accusative preceded by prepositions: nu iaste ca îns dentru cei de pre pămînt om (Iov, 2, 3), să-i facem lui agiutor cătră însul (Fac, 2, 18), sedzu cu însele Avram împreună (Fac, 15, 11), nu întoarse Iosia fața lui de cătră însul (2Paral, 35, 22), veți mînca den însul (Fac, 3, 5), cetățile întru carele întru înse lăcuia Lot (Fac, 19, 29), era la însă o slujnică eghipteanină (Fac, 16, 1), și el sta lîngă înşii (Fac, 18, 8), și-lpusă pre îns în grădină ca să o lucrêdze pre însă $(F a c, 2,15)$, etc.

The pronoun dinsul (explained either by de $+{ }^{*}$ ipsu or $\check{i d}+{ }^{*}{ }_{i} p s u$, see Arvinte, 1991, p. 18, 19, or by de + insul, see Frâncu, 2009, p. 53) is rarely used: s-au întorsu la dînsul (Fac, 8, 9); in feminine - dînsă $/$ dînsa: care era la dînsă în casă (Fac, 27, 15), la dînsa cască și căscînd gura o privăsc pre ea $(3 E z d, 4,19)$, and in plural masculine - dînșii: au grăit cătră dînșii (3Reg, 12, 14). Feminine plural forms are not recorded. 2.2.2. The frequent use of dative conjunct forms of personal and reflexive pronouns having the value of possessive adjectives, in all persons including plural, is also considered a characteristic of the pronoun morphology in old Romanian (Arvinte, 1991, p. 20; Frâncu, 2009, p. 62): premine să mă aşedzu la boieriemi (Fac, 41, 13), voi știți că fămêia-mi doi mi-au născut (Fac, 44, 27), vei lua de la aproapele-ți (Lev, 25, 15), potoli limba ta de rău și budzele-ți ca să nu grăiască vicleşug $(P s, 33,13)$, dă denlontru fata-ți $(\operatorname{Sir}, 7,26)$, întru tinerêț̦ele-ți n-ai adunat, și cum vei afla întru bătrînêțele-ți? (Sir, 25, 5), de sînteți sănătoși și fiii-vă și ale voastre după voie vă sînt voao, rogu-mă, dară, lui Dumnedzău cel prea mare, har, la cer nădèjdea avînd (2Mac, 9, 20), va scoate gușea-i (Lev, 1, 16), bătea pre măgărița-i cu toiagul (Num, 22, 27), ceară fieștecarele de la vecinu-și (Ieș, 11,2), grăiră întru budzele-și $\left(P_{s}, 21,7\right)$, să margă cu sănătate cătră părintele-și (Tov, 8 , 16), și ia omul sabiia lui și iêse la ieșire-și să tîlhărească $(3 E z d, 4,23)$.

2.2.3. In the old Romanian, the demonstrative of identity was presenting two parallel series. The first (which no longer exists in modern Romanian) was the result of the composition of the nearby demonstrative pronoun $+s ̦ i$ (cf. GALR, p. 248) - acestaşi: acestaşi vrînd să facă chip celor ce lîngă ei lăcuia jidovi

\footnotetext{
${ }^{1}$ The last example is also discussed by Frâncu (2009, p. 267).
} 
(2Mac, 12, 8), întru acestași chip (Iosip, 11, 11) / aceastași: puse pentru aceastași Efraim (Osia, 8, 9), tot cela ce cercetează întru aceastași (Zah, 10, 4) / acêsteași: iarăși mergînd și acêsteași făcînd (Sir, 34, 28), de cîte ori ție ți să pare pentru acêsteași sîngure să-ți porîncescu (3Mac, 5, 37). While in the current Romanian the identity opposition operates only "around non-proximity (același / celălalt)", in the old Romanian the opposition also worked within the proximity: acestaşi / cestălalt (GALR, p. 242) nu veniia cu cestalalt (Cuv. II, 909/12).

2.2.4. Another feature of the old language illustrated by ms. 45 consists of two variants of using the pronoun and relative-interrogative adjective care: a variable one on the one hand, and a unique, invariable one on the other (Densusianu, 1932, p. 189; Arvinte, 1991, p. 20; Frâncu, 2009, p. 67 ș.a.). As variable forms we record, in nominative and accusative: carele (singular masculine or plural feminine): pre om pre carele l-am făcut (Fac, 6, 7), şi săvîrși Dumnedzău în a șêsea dzi faptele lui carele au făcut (Fac, 2, 2), carea (feminine singular): muiêrea carea ai dat cu mine (Fac, 3, 12), carii and carei, masculine plural: și veniia toți înțelepții carii făcea toate lucrurile sfintului (Ieș, 36, 4), ficiorii lui Enac, voi pipăi stîlpii preste carei casa iaste răzămată (Jud, 16, 26).

2.2.5. The use of non-articulated forms of the indefinite pronoun with the meaning of 'something else' is also considered (Densusianu, 1932, p. 191; Frâncu, 2009, p. 69) a feature of the old Romanian: nici iaste altă nimic rădicat de la mine färă de tine (Fac, 39, 9), eu sînt și nu iaste altă $(I s, 47,8)$, și dziceați: «ce altă, fără numai sămînță cerceteadză Dumnedzău?» (Mal, 2, 15), de teslari și zlătari meșterșuguite sînt, altă nemic, au doară să să facă care vor meșterii să să facă iale (Ep Ier, 1, 39), etc.

\subsection{Verbs}

2.3.1. In ms. 45 the preservation of some verbs of $2^{\text {nd }}$ or $3^{\text {rd }}$ conjugation is confirmed. Thus, the verbs: $a$ ținea (< Lat. tèneō, -ère): și-lvorținea preînsul în vêci $($ Ieș, 32, 12), a rămînea (< Lat. remaneō, -ère): pînă nu va rămînea acoló nici piatră $(2 R e g, 17,13)$, a împlea (< Lat. impleō, -ère): și le vei împlea mînele lor $($ Ieș, 28, 37), a mînea (< Lat. maneō, -ère): voi mînea la Ravaoth a pustiiului pînă va veni cuvîntu de la voi (2Reg, 15,28$)$ still preserve the $2^{\text {nd }}$ conjugation. The verb a adaoge (Lat. adaugère): nu va mai adaoge a da ție putêrea lui (Fac, 4, 11), nu voi mai adaoge încă a blăstăma pămîntulpentru faptele oamenilor, pentru că zace cugetul omului pre cêle rêle den tinerêțe, deci nu voi mai adaoge a omorî tot trupul viu (Fac, 8, 21), etc. preserves the $3^{\text {rd }}$ conjugation.

2.3.2. According to the rule of that time, in $\mathrm{ms} .45$ the palatalized forms in the first person (singular) of the present indicative and subjunctive, and in the third person (singular and plural) respectively, of the present subjunctive: eu - Dumnedzăul tău, cel ce țiiu drêptei tale $(I s, 41,13)$, căutaiu eu ca să văz învățătura (Ecles, 2, 12), iată, eu aprinzu întru tine foc (Iez, 20, 47), cu foc să să ardză (Lev, 13, 52), să-și întinză mîna (1Mac, 12, 39), să-i rădic pre înşii și să-i pierzu (Ier, 18, 7), arcul mieu puiu în noăr (Fac, 9, 13), nu putea frații să-i răspundză lui (Fac, 45, 3), eu viu cătră tine (Ieș, 19, 9), ca să saie cu iale pre pămîntu (Lev, 11, 21 ), etc. are recorded for the verbs belonging to the $2^{\text {nd }}, 3^{\text {rd }}$ and $4^{\text {th }}$ conjugations with their root ending in $d, t, n$.

2.3.3. At imperfect, the forms of the third person plural have zero ending: toți cîți ieșiia den poarta cetății lor (Fac, 34, 24), ceia ce mergea (Ieș, 14, 28), aşa făcea tinereii (Jud, 14, 10), etc.

2.3.4. Strong perfects of the $3^{\text {rd }}$ conjugation verbs ending in $s,(s u, s i u)$ in the first person singular are part of the norm (Gheție, 1997, p. 137, 338): şi eu mă puş impărat de însul preste Sion (Ps, 2, 6), dăşchiş eu frățiorului mieu (Cînt, 5, 7), și eu dziș (Ier, 3, 19), și aduş cătră ei toate cuvintele făgăduinței aceștiia carea am porîncit ca să facă, și n-au făcut (Ier, 11, 8), și rămaş eu sîngur (1Mac, 13, 4), și mă întorșu eu (Ecles, 4, 1), și merșu și-l ascunșu la Efrath, în ce chip au porîncit mie Domnul (Ier, 13, 5), mă întorșiu surorii mêle (Fac, 30, 7), etc.

\footnotetext{
${ }^{2}$ Ms. 45 features both a dedicatory foreword of the copyist: Cuvîntu înaintea cărții aceștiia cătră preasfințitul mitropolit [Foreword of this book to his holiness the metropolitan bishop] (= Cuv. I), as well as a Cuvîntu inainte cătră cititori [Foreword to the readers] (= Cuv. II).
} 
2.3.5. The preterite forms of the verb $a$ da that occur in ms. 45 belong exclusively to the strong paradigm ${ }^{3}$ : şi eu dediu lui (Ieş, 31, 6), mîncă și dêde și bărbatului ei (Fac, 3, 6), ș şi dêderă lui Iacov pre bodzii cei striini (Fac, 35, 4), etc.

A feature of the era is the lack of the inflectional suffix $-r a ̆$ in the plural forms of the first and second person of the preterite (cf. Frâncu, 1967, p. 175-192): și-i dzisem lui (Fac, 42, 31), și pogorîră părinții noștri la Eghiptu, și nemernicim la Eghiptu dzile multe (Num, 20, 15), iată am audzit pre ea în Efrathá, afläm pre ea întru cîmpii dumbrăvii $(P s, 131,6)$, aceluia nu putum opritori să fim (Sus, 1, 38), etc.

2.3.6. In the pluperfect, no plural form contains the inflectional suffix $-r a ̆ a$. The distinction between singular or plural of the third person in $-s e$ or $-s a ̆$ is dictated by the context: grăi cătră ginerii lui, ce-i luasă fêtele lui (Fac, 19, 14), și Iacov păștea oile lui Lavan ce rămăsêse (Fac, 30, 36), toți ceia ce-l vădzuse pre el (1Reg, 10, 11), ceia ce rădicase mîna lor preste domnul mieu (2Reg, 18, 28), și cădzu zidul preste 27000 de oameni, cei ce rămăsêse (3Reg, 20, 30), dreptatea mă îmbrăcase și mă învăscuse cu județul (Iov, 29, 14), etc.

2.3.7. In the present perfect, the auxiliary of the third person singular au, explained by the influence of the third person plural (au < *habunt, see Frâncu, 1969, p. 303, or from habuit, see Sădeanu, 1959, p. 316; Gheție, 1973, p. 421-430) is also a tense specific to the old age (cf. Frâncu, 1969, p. 299-318; Gheție, 1973, p. 421-430): au dzis Domnul (Fac, 3, 1), au aflat robul tău har (1Reg, 27, 5), brațullorn-au mîntuit preînsii $(P s, 43,4)$, etc.

2.3.8. Several forms of present subjunctive far different from today highlighted in previous studies (Arvinte, 1988, p. 79; Arvinte, 1991, p. 23), are to be found in ms. 45: the verb a avea has at the $2^{\text {nd }}$ person singular the form să aibi: pentru ca să aibi oi de imbrăcăminte (Parim, 27, 26), the verb a adaoge ( $3^{\text {rd }}$ conjugation) has the third person să adaogă: acêstea să facă Dumnedzău lui Ionáthan și acêstea să adaogă (1Reg, 20, 13), and the second person plural form să adaogeți: să nu mai adaogeți (Fac, 44, 23), ca să adaogeți păcatele lui Israil $(3 E z d, 9,7)$.

2.3.9. The auxiliary of the perfect conjunctive presents in $\mathrm{ms}$. 45 forms inflected by person and number: după acesta fu altul, Simah, carele zic să fie fost samaritean, apoi să să fie făcut jidov (Cuv. II, 908/1), cîndai să nu fim greșit ceva cătră tine (Fac, 20, 9), arată-te pre tine mie cunoscut să te vădzu, pentru ca să fiu aflat har înaintea ta (Ieș, 33, 13), de folos să him pierit întru pierirea fraților noștri (Num, 20, 3), audzit-am eu fetişoara să să fie dat la 7 bărbați (Tov, 6, 13), aceștia să fie căzut (2Mac, 12, 40), fiarăle și puterile să să fie gătit (3Mac, 5, 29), cum unii foarte să să fie bucurat (Iosip, 4, 22), etc.

2.3.10. As in other texts of that time, in $\mathrm{ms} .45$ there are also several cases where the long infinitive covers the functions of the supine (cf. Frâncu, 2009, p. 128): tot lemnul care are întru sine roadă de sămînță sămănătoare voă va fi de mîncare (Fac, 1, 29), voi da pre morții lor la mîncare pasărilor ceriului și fiarălor pămîntului (Ier, 19, 7).

\subsection{Numerals}

The fractional numeral occurs only with the old forms. To express the ratio part / total, noun phrases with parte are employed: și veți da a cincea parte lui faraon, iară cêle patru părți vor fi voao pentru sămînța pămîntului (Fac, 47, 24), şi trimise David nărod, a treia parte cu mîna lui Ioav (2Reg, 18, 2), etc.

\subsection{Expressing superlatives}

At the absolute superlative of adjectives and adverbs, the cases of postposition and dislocation of the adverb foarte from the adjective or when the adjective / adverb lacks are considered standard features of the era (Frâncu, 2009, p. 49, 276): ficioara era frumoasă la față foarte (Fac, 24, 16), foarte straşnic iaste locul acesta! (Fac, 28, 17), să umiliră oamenii și cu scîrbă le era foarte lor (Fac, 34, 7), au băut vin mult foarte (Idt, 12, 18), te voi înmulți foarte (Fac, 17, 2), nu vă duceți departe de cetate foarte (Ios, 8, 4), și mă temui tare foarte (Neem, 2, 2).

\footnotetext{
${ }^{3}$ For details about the history of the perfect simple regarding the verbs a da and a sta, see Frâncu (1980, p. 309).
} 


\subsection{Prepositions}

2.6.1. The prepositions encompass different values; intru, for instance, often takes the meaning of 'as, in its quality as': și-mi veți da mie copila aceasta întru fãmêie (Fac, 34, 12), și puse lor întru porîncă pînă în dzua de astădzi pre pămîntul Eghiptului a da a cincea lui faraon (Fac, 47, 26), etc.

2.6.2. Cătră occurs in ms. 45 with different values; in many cases, it has a local meaning 'towards': vezi den locul carele acum tu ești cătră miadzănoapte, și cătră amiadzădzi, și cătră răsărit, și cătră mare (Fac, 13, 14), intinde-voi mîna mea cătră Domnul Dumnedzău cel preaînaltu (Fac, 14, 22), 'to': și o aduse pre însă cătră Adam (Fac, 2, 22), pentru căci ați venit cătră mine? (Fac, 26, 27). Frequently, cătră also has the meaning of 'vis-à-vis': și voi întări făgăduința mea cătră însul întru făgăduință vêcinică $(F a c, 17,19)$, și eu nu m-am îndurat de tine pentru ca să nu greșești tu cătră mine (Fac, 20, 6), greșit să fiu cătră tine toate dzilele (Fac, 43, 9), ce-s paiele cătră grîu? (Ier, 23, 28). Rarely, cătră has a temporal meaning: vor giunghia pre el toată mulţimea adunării fillor lui Israil cătră sară (Ieș, 12, 6), și mielul al doilea îl vei face de cătră sară (Ieș, $29,41)$, etc.

2.6.3. Spre also occurs with its etymological value (that of Lat. super), which gradually disappeared as a result of its competition with pre (cf. Frâncu, 2009, p. 141): că voi aduce răutățile spre tine (1Reg, 20, 13), glasul Domnului spre ape (Ps, 28, 3), etc. In some contexts, spre has the meaning of 'as, in its quality as': şi dzise mie Dumnedzău: Solomon, fiul tău, va zidi mie casă și ograda mea, căci am ales întru însul, să-mi fie mie ficior și eu voi fil lui spre părinte (1Paral, 28, 6), și ședzu Solomon pre scaunul domnului spre împărat pentru David, tatăl lui, și să binevru și ascultară lui tot Israil (1Paral, 29, 23), și va fi întru dzua acêea, fi-va tot locul unde vor fi 1000 de vii de 1000 de sicli, spre țêlină vorfi și spre spini $(I s, 7,23)$, te-am dat pre tine spre făgăduială rudeniei mêle $(I s, 42,6)$, am ajutat ție și te-am zidit și te-am dat spre făgăduință limbilor $(I s, 49,8)$.

\subsection{Conjunctions}

The conjunction $s \breve{a}$ still retains its primary conditional value inherited from Latin (Lat. $s \bar{\imath}>s e>s \breve{a})^{4}: s \breve{a}$ nu voi eu trêce la tine, nice tu cătră mine vei trêce movila aceasta (Fac, 31, 52), să nu vei vrea să-l trimiţi pre însul, iată, eu lovescu toate hotarăle tale cu broaște (Ieș, 8, 2), să veți întra în pămîntul carele va da voăa Domnul după cum au grăit, cruțtați slujba aceasta (Ieş, 12, 25), să va zdrobi dintele robului sau roabei lui, volnici ii va trimite pre ei pentru dintele lor (Ieş, 21,27), să va mîncîndu mînca-va den cărnuri a treia dzi, nu va priimi celuia ce-i aduce lui (Lev, 7, 8).

\section{Innovations}

In ms. 45 a number of changes in the morphological system can be identified - some of them in their early stages, others in their advanced stages.

\subsection{Nouns}

3.1.1. Gender variations are recorded both in the case of personal animated nouns, as in the case of inanimate nouns. For example, the feminine form of slugă has a high frequency: slugă va fi fraților lui! (Fac, 9, 25), etc.; the masculine form, arising out of the context, is very rare: si, audzindu Avram cum s-au robit Lot, nepotul lui, numără pre ai lui slugi de casă 318 (Fac, 14, 14), va da dare dentru moştenirea lui unuia dentru slugile lui (Iez, 46, 18), pre slugi i-au omorît cu sabii (Iov, 1, 17).

In what concerns the inanimate nouns, the masculine - neutral variations have been correlated with the occurrence or generalization of plurals (Frâncu, 2009, p. 24). The variation can be illustrated, for example, with the noun belcing, that occurs only once in the plural belciuge (neutral gender): și vei face

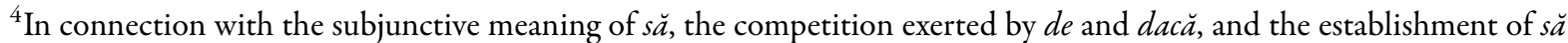
as the morpheme of the subjunctive (which had the effect of favoring the replacement of the infinitive by the subjunctive, but also losing the opportunity of $s a ̆$ to be combined with the indicative and the conditional), see Frâncu (2000, 2009).
} 
Ana-Maria Minuț

belciuge de aur, 50 (Ieș, 26, 6) and four times with the masculine form belcingi: și vei face 50 de belciugi de aramă și vei împreuna belciugii den chiotori de căpețêle (Ieș, 26, 11), etc.

The plural form rărunchi (masculine) has 20 occurrences: amîndoi rărunchii (Ieș, 29, 13), etc., while the neutral form has only three occurences: pre amîndoao rărunchele (Lev, 3, 10), si amîndoao rărunchile $($ Lev , 4, 9). Cîmp (< Lat. campus) occurs in the plural 22 times with the masculine form cimpi: bucate cîmpilor cetății (Fac, 41, 48), toți oamenii și dobitocul cîte să vor afla în cîmpi (Ieş, 9, 19), etc. The neutral form cîmpuri occurs four times: unde-s pîraie de apă și izvor a fărăfundurilor ieșindu pre cîmpuri și pren munți (Deut, 8, 7), etc.

Similarly, we notice, in the plural, both the masculine form genunchi and the neutral genunche: siși puse obrazul lui intru mijlocul genunchilor lui (3Reg, 18, 42), I și l-au adormit pre el intru mijlocul genunchelor ei (Jud, 16, 19). The plural form umere: pre doao umere a lor (Ies, 28, 21), 4 umere (3Reg, 7, 34) alternates with umeri: pre umeri puind cunună (Iov, 31, 36), preste umeri să poartă (Ep Ier, 1, 22), etc.

For other nouns reported in the literature, we found in ms. 45 no gender variations either because the new forms had already generalized or because the innovations had not manifested yet. The first category includes, for example, $\operatorname{grumad}(z)$ and $s t i ̂ l p$, which generalized their masculine form, having in the plural only gruma (d)zi and stîlpi, respectively: au cădzut la grumadzii lui (Fac, 33, 4), să zdrobești stîlpii lor (Ieș, $23,24)$. In the second category we record nouns such as veac (< O.Slav. věkŭ), masculine, which only occurs with the plural form vêci (and not veacuri): și va trăi în vêci (Fac, 3, 22), întru vêcii vêcilor lăudate-vor pre tine $(P s, 83,5)$, or obra $(d) z$, which still belongs to neutral gender, with the plural obra $(d) z e$ : și obrazele lor, unul cătră altul, cătră acoperemîntu vor fi obradzele heruvimilor (Ieş, 25, 20), ruşinat-ai astădzi obradzele tuturor robilor tăi (2Reg, 19, 5), ia vino să ne ivim la obraze! (4Reg, 14, 8). The plural clopoți (masculine) falls into the same category: și au fácut clopoți de aur (Ieș, 39, 24), și clopoți de aur 400 (2Paral, 4, 13), and was considered by Arvinte (1991, p. 16) "a remarkable linguistic peculiarity", evidenced by N.A. Ursu in the context of the debates undertaken on the text authorship.

The neutral - feminine variations were correlated with the imposition of some singular forms (Frâncu, 2009 , p. 24), with repercussions on their assignment to a declension or another. On the one hand, in ms. 45 the neutral form of $\operatorname{rod}(u)$ : nu va fi întru voi fară de rodu $($ Deut $, 7,14)$, with the plural roduri: cêle dentîi roduri a pămîntului tău vei aduce inlontru în casa Domnului Dumnedzăului tău (Ieș, 34, 26), is recorded. On the other hand, there is also the feminine road $\breve{a}^{5}$ : lemnu roditor făcindu roadă (Fac, 1, 11), veți minca roada lui (Lev, 19, 25), explained according to the plural form roade.

The feminine pustie, closer to the etymon (Bulg. pustinja) occurs alongside the newer form pustiiu, belonging to the neutral gender: voi pune pre Nenevi spre stingere, fără de apă, ca o pustie (Sof, 2, 13) / să duse de tăbărî in pustiiu (Fac, 12, 9). Buruian, of neutral gender, originated from Slav. burjanŭ (Arvinte, 1988, p. 70), occurs six times (once, in a marginal note): ca ploaia pre troscot și ca ninsoarea pre buruian (Deut, 32, 2), ca un buruian ce să pornêște de vînt stai împotriva mea? (Iov, 13, 25), etc. The feminine form, buruiană, occurs three times: răsaie pămîntul buruiană de iarbă sămănătoare (Fac, 1, 11), budza rîului mainte de toată buruiana să va zmulge (Sir, 40, 18).

3.1.2. Regarding the grammatical category of number, in $\mathrm{ms}$. 45 the replacement stages of the $-e$ plural ending by the $-i$ ending can be traced in a number of feminine nouns ${ }^{6}$ : for instance, aripa only has the plural ending $-i$ : aripi de vultur (Ieș, 19, 4), while pulpă (also with the root in $-p$ ) occurs only once with the plural pulpi: să te bată Domnul cu rană rea preste genunchi și preste pulpi (Deut, 28, 35), but five times with the form pulpe: pulpele lui - de marmure (Cînt, 5, 16), etc.; limbă has both forms with $-e$ and with $-i$ in plural: toate limbele (1Reg, 8, 20), / intru limbile lor (Fac, 10, 5); likewise, inimă occurs both with $-e$ and with $-i$ in plural: tu ești cel ce cerceteadză inime (1Paral, 29, 17) / inimile voastre (1Reg, 6, 6), etc.

The alternation, within the same noun, of the plural endings - uri / $-e$ is found in neutral nouns such

\footnotetext{
${ }^{5}$ This occurred in Moldova at the beginning of the $17^{\text {th }}$ century (Frâncu, 2009, p. 24).

${ }^{6}$ For more details on this process, see Densusianu (1932, p. 151-153), Diaconescu (1970, p. 116-126), Frâncu (2009, p. 30-32).
} 
as nărod (norod), zăgaș, etc.: acêstea-s nărodurile lui Ghedsom (Num, 3, 21) / după năroadele lor (Num, 4, 30); vor seca rîurile și zăgașurile rîului $(I s, 19,6)$ / întinde cu mîna ta toiagul tău pre rîuri, și pre zăgașe $($ Ieş, 8, 5).

In ms. 45 , both the etymological plural of numere (< Lat. nomina), or possibly numeri (by replacing the ending $-e$ with $-i$, as it is frequently seen in the articulated forms numerile), as well as the form nume, homonymous to the singular (this latter attested in the southern texts as early as 1551-1553, cf. Frâncu, 2009, p. 26): și acêstea-s numerile a fiilor Isav (Fac, 36, 10), acêstea-s numerile hatmanilor Isav (Fac, 36, 40), I aceștia sîntu ficiorii lui Ismail și acêstea-s numele lor (Fac, 25, 16), și acêstea-s numele ficiorilor lui Israil (Fac, 46, 7), numele părinților miei (Fac, 48, 16).

3.1.3. Ms. 45 reflects the general trend of simplifying the nominal flexion by the modification of the feminine nouns in genitive-dative, of the flectives formed by the ending $(-e$ or $-i)$ and definite article $(-e i)$ (cf. Diaconescu, 1970, p. 206; Frâncu, 2009, p. 36). Thus, in nouns that have in the singular (nominative-

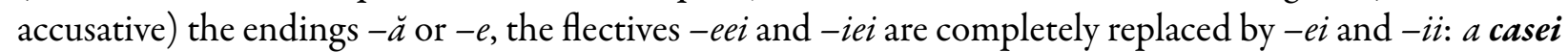
tale (Fac, 17, 12), toate ciniile casii mêle (Fac, 31, 36), fêtei lui (Fac, 29, 24), a pizmei (Is, 13, 9), dedesuptul budzii ei (3Reg, 7, 24), la marginile lumei (Ps, 18, 4), nădêjdea lumii (Sol, 14, 6), dzua morții mêle (Fac, 27, 2), păzitoriul grădinei (Neem, 2, 8), a grădinii împăratului (4Reg, 24, 24), etc.

A feature of the texts during that period of time, confirmed by ms. 45 , is the genitive-dative in -iii in nouns whose nominative-accusative form end in -ie and with plural in --i: semințiii tale voi da pămîntul acesta (Fac, 12, 7), au ascultat Domnul smereniii tale (Fac, 16, 11), începăturile ariii tale (Ieş, 22, 29), usăbirea necurățiii ei (Lev, 18, 19), păcatele preuţiii voastre (Num, 18, 1). But the forms with -iei have a higher frequency: și veți sluji slujbele dare preuției (Num, 18,7), seminției voastre voi da pre el (Deut,

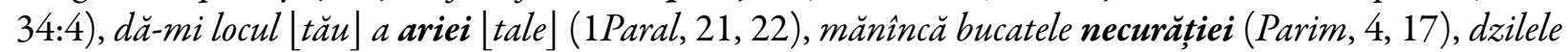
smereniei lui (Plîng, 1, 8), etc.

3.1.4. A number of changes in the declension system are well illustrated by ms. 45 . It is, on the one hand, about the early stages, the shift from a declension to another and, on the other hand, about the advanced stages, where the new classification of the declension is not fully realized.

Thus, with regard to the shift from the $3^{\text {rd }}$ to the $1^{\text {st }}$ declension, some nouns have several forms specific to the $3^{\text {rd }}$ declension, while regarding other nouns the forms of the $1^{\text {st }}$ declension already dominate. For example, the form of $3^{\text {rd }}$ declension arame occurs 15 times: toate vasele lui le-au făcut de arame (Ieș, 38, 3), grătariul cel de arame (Ieș, 39, 40), etc., while the form of the $1^{\text {st }}$ declension aramă is more common (160 occurrences): era bătător de ciocan și faur de aramă și de hier (Fac, 4, 21), le vei acoperi cu aramă (Ieș, 27, 2), și vase de aramă, de aramă bună, sclipind in fêliul aurului, vase 12 (3Ezd, 8, 59), etc. Instead, the form of $3^{\text {rd }}$ declension peștere (articulated, peșterea) is much better represented ( 43 occurrences): și lăcui în peștere, el și [2] fête a lui cu însul (Fac, 19, 30), și-mi dea peșterea cea îndoită carea iaste lui (Fac, 23, 9), deșchideți peșterea (Ios, 10, 22), in comparison to peșteră, articulated, peștera, with two occurrences, as in: îngropați-mă cu părinții miei întru peștera carea iaste întru țarina a lui Efron (Fac, 49, 29).

A phonetic change, but with morphological repercussions signaled by many experts (Vasiliu, 1968; Gheție \& Mareș, 1974; Gheție, 1975; Frâncu, 2009, etc.) focuses on the nouns with their theme in ş, j. If $s$ and $j$ were palatalized until around 1640 in the northern dialects (forms such as mătuşe, grije of $3^{\text {rd }}$ declension were regarded as being normal) while in the southern vernaculars they were strong (mătuşă, grijă of $1^{\text {st }}$ declension), starting in 1640-1670 de-palatalization occurred in the north, while palatalization occurred in the south. While for the noun $u s ̧ a$, , for example, the membership to the $3^{\text {rd }}$ declension is proven by the 53 occurrences of the form uşe and of the articulated form uşea: ușea o trase după însul $($ Fac , 19, 6), întingîndu dîn sîngele de lîngă uşe (Ieş, 12, 22), etc.; the $1^{\text {st }}$ declension is represented by the 63 occurrences of the articulated form uşa (uşă, the unarticulated form, is not recorded): grăiră lui întru uşa casei dzicîndu (Fac, 43, 19), stătu Moisi pre uşa taberii (Ieş, 32, 25), etc.

Regarding the shift from the $2^{\text {nd }}$ to the $3^{\text {rd }}$ declension, it is obvious that some nouns occur only with output forms of $3^{\text {rd }}$ declension, for example imbrăcăminte, incălțăminte (the older forms of $2^{\text {nd }}$ declension, îmbrăcămînt, încălțămînt not being recorded): luîndu Revéca îmbrăcămintea lui Isav (Fac, 27, 15), 
Ana-Maria Minuț

dezleagă încălțămintea den picior (Ieş, 3, 5), etc. In case of other nouns, the forms of the $2^{\text {nd }}$ declension coexist with those of $3^{\text {rd }}$ declension: ca un vultur va porni (Ier, 48, 40) / ca o pornire de vulture (Deut, 28, 49), să te bată Domnul cu rană rea preste genunchi (Deut, 28, 35) / să plecă pre genunchele lui înaintea lui Iliú (4Reg, 1, 13), etc.

Regarding the shift from the $3^{\text {rd }}$ to the $2^{\text {nd }}$ declension, the case of the female form pustie of $3^{\text {rd }}$ declension, closer to the etymon (< bg. pustinja, cf. also Frâncu, 2009, p. 20), which occurs alongside the newer form pustiiu, belonging to the neutral gender and to the $2^{\text {nd }}$ declension, can be brought up: să nu vă impreunați, rătăcind în pustie (Is, 16, 8), și va fipămîntul Eghiptului pierire și pustie (Iez, 29, 9), / să duse de tăbărî in pustiiu (Fac, 12, 9), carele iaste in pustiiu (Fac, 14, 6). More nouns meet only specific forms of the $3^{\text {rd }}$ declension: iată un berbêce prinsu într-un sádu savec de coarne (Fac, 22, 13), și vei junghea berbêcele (Ieș, 29, 16), capul berbêcelui (Ieș, 29, 19), urîciunile și șoarecile $(I s, 66,17)$, vădzîndu cum au zemislit în pîntece (Fac, 16, 5), și luă în pîntece de la el (Fac, 38, 18), cămila, și iepurile, și ariciul, (...), necurate voao vorfi (Deut, 14, 7).

In the definite articulated plural minule (manu + art. $-l e$ ), which occurs 45 times in ms. 45, we can see traces of the $2^{\text {nd }}$ declension (a remnant of the $4^{\text {th }}$ Latin declension; cf. also Dimitrescu, 1978, p. 199; Arvinte, 1991, p. 16): mînule lui pre toți și mînule tuturor pre însul (Fac, 16, 12), vădzu cerceii și brățările în mînule sororei lui (Fac, 24, 30), dêde bucatele și pîinele carele au făcut pre mînule lui Iacov (Fac, 27, 17), etc. In ms. 45, the analoguous plural form mînele are also encountered: luați voi mînele pline de spudză den cuptoriu (Ieș, 9, 8), mînile (unarticulated, mîni): fapte de mîni omenești (Deut, 4, 28), și nu lua sama oamenilor cărora da argintul pre mînile lor $(4 \mathrm{Reg}, 12,15)$, mîinele (unarticulated, mîine): $̂ l$ va scoate den mîinele lor (Fac, 37, 21), argintul îndoit luați întru mîine voastre (Fac, 43, 12), mîinile (unarticulated, mîini): voi întinde mîinile mêle cătră Domnul (Ieş, 9, 29), și luînd preutul unsul, cel săvîrşit, la mîini (Lev, $4,5)$.

Oscillations between the $2^{\text {nd }}$ and $1^{\text {st }}$ declension are recorded as follows: rodu, of $2^{\text {nd }}$ declension and

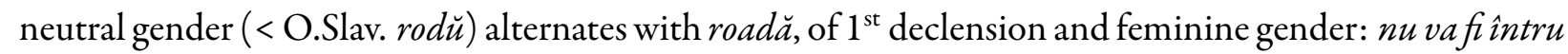
voi fără de rodu (Deut, 7,14$)$ / tot lemnul care are întru sine roadă de sămînţă sămănătoare (Fac, 1, 29), veți mînca roada lui (Lev, 19, 25), vei aduna roada ei (Lev, 25, 3).

\subsection{Verbs}

3.2.1. Like other texts of that time, ms. 45 evidences cases of shifting from the $3^{\text {rd }}$ to the $1^{\text {st }}$ conjugation and from $4^{\text {th }}$ to $3^{\text {rd }}$ conjugation, or of oscillations between $1^{\text {st }}$ and $4^{\text {th }}$ conjugations.

Regarding the shifting of some verbs from the $3^{\text {rd }}$ to $1^{\text {st }}$ conjugation, it can be noticed that in ms. 45 the verb a cure (< Lat. currĕre) has in third person of present indicative the form cură: la pămîntul ce cură miêre și lapte (Ieș, 3, 8), etc. The same verb presents forms of imperfect specific to the $1^{\text {st }}$ conjugation: apele cêlea ce cura den sus (Ios, 3, 16), balele lui cura preste barba lui (1Reg, 21, 13), etc.

The participle form invis is explained by the form of $3^{\text {rd }}$ conjugation a invie, but the form of participle inviat shows the transition to the $1^{\text {st }}$ conjugation, a invia: și fu el povestind impăratului cum au invis fiul ei cel mortu (4Reg, 8, 5), și iaste scris cum el iarăși să să fie învis cu carii Domnul au învis $($ Iov, 42, 16) / și intorcindu-te m-ai înviat $\left(P_{s}, 70,22\right)$. Within the structure of the future tense, the verb in question is used both with the form of $3^{\text {rd }}$ conjugation (two occurrences), and with the form of $1^{\text {st }}$ conjugation (seven occurrences): nu va învie inimile necredincioșilor și judêțele săracilor va da (Iov, 36, 6) / ințelepciunea va invia (Ecles, 7, 13), pre noi ne va înviia (2Mac, 7, 9).

The less uncommon shifting (Frâncu, 2009, p. 88) from the $4^{\text {th }}$ to the $3^{\text {rd }}$ conjugation can be illustrated by the verb a invești (< Lat. investire), which occurs in ms. 45 with forms of $3^{\text {rd }}$ conjugation: dă te vei învêște róșiu și te vei împodobi cu podoabă de aur (Ier, 4, 30), va învêște ruşine (Mih, 7, 10).

Several verbs that have arisen through derivation (from nouns to adjectives) either in the popular Latin or in the common Romanian (cf. Frâncu, 2009, p. 86) oscillate between $1^{\text {st }}$ and $4^{\text {th }}$ conjugations. Thus, the verb formed from the noun adevăr has forms of $4^{\text {th }}$ conjugation (a adeveri) and, more rarely, of $1^{\text {st }}$ 
conjugation (a adevăra): să va adeveri casa carea iaste în cetate zidită (Lev, 25, 30), adeveriți noao (1Reg, 6,2) / și de la minciună cine să va adevăra? (Sir, 34, 4).

The verb formed from the adjective curat usually occurs with forms of $4^{\text {th }}$ conjugation: $n u$ va curăți Domnul (Ieș, 20,7), va curăţi preutul casa (Lev, 14, 48), etc.; the $1^{\text {st }}$ conjugation was registered only once: cel ce place măriților curăța-va nedreptatea (Sir, 20, 28).

The verb formed from indelung has both forms with the inflexional suffix specific to the $1^{\text {st }}$ conjugation, as well as with that of the $4^{\text {th }}$ conjugation: pentru că nu voi trăi întru vac, pentru ca să îndălungăz la mînie; dăpărtează-te de la mine (Iov, 7, 16), cei ce îndălungază pre sine de la tine pier (Parim, 72, 26), nu voi îndălunga încă (Iez, 12,25), să nu îndălungezi darea celui ci să roagă (Sir, 4, 3) / fără numai pentru urgie nepriêtenilor pentru ca să nu-și îndălungească anii (Deut, 32, 27), și să nu îndălungești a le face acêstea $(I d t, 2,10)$, de la cel ce au făcut pre el îndălungêște-să inima lui (Sir, 10, 12).

The verb created from the adjective vîrtos has forms of $1^{\text {st }}$ conjugation, but the gerund form is specific to the verbs with the present infinitive in $-i$ : nu invîrtoșați inimile voastre $(P s, 94,8)$, dă veți iarăşsi învîrtoșa $(I s, 8,9)$ / învîrtoșindu-să pre Iavin (Jud, 4, 23), învîrtoșind a lui cerbice și inima lor (3Ezd, $1,50)$.

The observation also applies to the gerund form of the verb a scuipa (< Lat. *scupire): de vei scuipa preste el (Sir, 28, 13), as opposed to: scuipind mai nainte (2Mac, 6, 20).

3.2.2. As shown by Arvinte (1988, p. 78), the proximity tendency of the imperfect forms in -iia / -iia by those in $-i a$, $-e a$ of the $2^{\text {nd }}$ and $3^{\text {rd }}$ conjugations is well illustrated in ms. 45 : for the verb a iubi, the grammatical suffix -eá occurs once, in the morphemic structure of the third person singular form: iară Revéca iubea pre Iacov (Fac, 25, 28); for the verb a birui, the grammatical suffix of the imperfect is -iá in all 11 occurrences of the $3^{\text {rd }}$ person forms: lăcomia celor ce biruia pre el (Sol, 10, 11); for the verb a fugi, the suffix of the imperfect - eá has four occurrences: cela ce fugea la pustiiu (Ios, 8, 20), etc.

3.2.3. The formation process of a sigmatic paradigm of the verbs a avea, a fi, a vrea is still at an incipient stage: the forms of the $2^{\text {nd }}$ person singular fuseși, avuseşi, vruseși have each one occurrence: mult fuseși alăturat lîngă cuvîntul acesta (Cuv. I, I), și avuseși păstori mulți (Ier, 3, 3), jirtvă și aducere nu vruseși (Ps, $39,9)$, and the form of the $3^{\text {rd }}$ person singular vruse has one occurrence as well: intru mine vruse să mă fac eu intru impărat preste tot Israilul (1Paral, 28, 4). Otherwise, ms. 45 records only the old, asigmatic forms: fuiu ingropată cu bărbat (Rut, 1, 12), asupra mea fură acêstea toate (Fac, 42, 36), țarina și peșterea ce avu Avraam (Fac, 25, 10), nădêjde avu mai mult cel färă minte (Parim, 26, 12), și avură har (3Ezd, 6, 5), povățuiêște-mă întru calea porîncilor tale, căci pre însă vruiu (Ps, 118, 35), nu vru să mănince (2Reg, 13, 9), nu vrură a să întoarce (Ier, 8, 5), etc.

3.2.4. The forms of the perfect simple of the verb a face belong to both strong (etymological) and weak paradigm (which will impose itself in modern literary Romanian; see Guţu Romalo, 1965, p. 337-540; Gheție, 1997, p. 137). In ms. 45 the strong (etymological) forms are only in the $3^{\text {rd }}$ person, singular and plural: și să fêce lumină (Fac, 1, 3), și fềce Dumnedzău chitoásele cêle mari și tot sufletul vitelor tîrîitoare (Fac, 1, 21), și să fêce dimineață (Fac, 29, 25), și să fêcceră toate dzilele lui Maleleil ani 895 (Fac, 5, 17), și i să fềceră lui oi, și vițăi, și măgari, și slugi, și slujnice, muşcoi și cămile (Fac, 12, 16).

Weak forms occur in all persons: în dășertu mă făcuiu (1Reg, 26, 21), mă făcui turburat $(P s, 29,9)$, te făcuși ajutoriul mieu (Ps, 62, 7), te făcuși mie întru mîntuire $(P s, 117,28)$, de-nceput făcu Dumnedzău ceriul și pămîntul (Fac, 1, 1), potopul apei să făcu pre pămîntu $(F a c, 7,6)$, și ne făcum asupra lor pînă la uşa porții (2Reg, 11,23), și făcură impregiurători (Fac, 3, 7), și să făcură fiii Ulam tari la vîrtute (1 Paral, 8, 40), etc.

3.2.5. The negative imperative forms of the $2^{\text {nd }}$ person plural built on long infinitive (+ ending $\left.-t i\right)$ are rare: nu vă têmereți (1Reg, 12, 20), dzua aceasta sfintă-i Domnului, nu vă mîhnireți (3Ezd, 9, 54). Most forms are identical to the present indicative: nu faceți strîmbătate copilașului (Fac, 42, 22), nu rădicați la inălțime cornul vostru, \și] nu grăiți asupra lui Dumnedzău strîmbătate $(P s, 74,5)$, etc.

3.2.6. The participle form of the verb a cere is both cerşut, as in other old texts (Arvinte, 1991, p. 24): 
după toate cîte ai cerșut de la Domnul Dumnedzăul tău la Horiv (Deut, 18, 16), i-au dat lui cetatea carea au cerșut (Ios, 19, 50), as well as cerut: cerînd s-au cerut de la mine David (1Reg, 20, 6), au cerut Solomon cuvintul acesta (3Reg, 3, 10), n-ai cerut avuție de bani (2Paral, 1, 11).

The verb a face has only got the participle form of făcut, generalized around 1640-1650 (Frâncu, 2009, p. 322), which replaces the etymological form fapt (closer to the Lat. etymon factum): intru care dzi au făcut Domnul Dumnedzău ceriul și pămîntul (Fac, 2, 4), etc. However, the verb a sta has exclusively the participle form of stătut, explained from the root of simple perfect stătu (Frâncu, 2009, p. 131): vădzu Lia că au stătut de a mai naște (Fac, 30, 8), ați stătut suptu munte (Deut, 4, 11), cu strîmbătate au stătut impotriva fratelui său (Deut, 19, 18), nime n-au stătut împotrivă (Ios, 23,9), stătut-ați prestă sabiia voastră $($ Iez, 33, 26).

\section{Specific elements}

\subsection{Elements taken from the Greek text}

Regarding the specific elements of the text, we notice, on the one hand, a number of language facts explained by the Greek text, many of them highlighted by Vasile Arvinte in his study on the Bible of Bucharest. 4.1.1. Within the class of non-prototypical nouns we can include nouns taken from Greek such as the massive pielm ('dough of wheat flour (without yeast)' < Gr. $\pi \dot{\varepsilon} \lambda \mu \alpha,-\alpha \tau o \xi)$ ) și frămîntară pielmul ce l-au

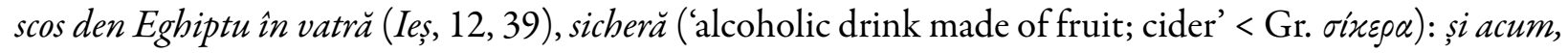
te păzêște și să nu bêi vin și sichera (Jud, 13,7), name of dyes and paints such as minău (var. of miniu 'lead oxide, red-orange, insoluble in water, used for painting' < Gr. $\mu$ ivio): văruite cu minău $(\operatorname{Ier}, 22,14)$ and

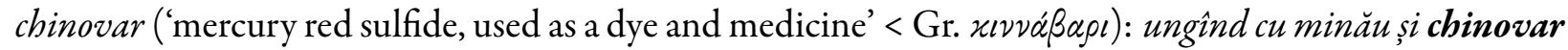
(Sol, 13, 14), names of substances and herbs such as nard ('fragrant essence extracted from the root of

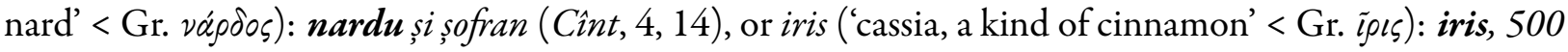
de sicli (Iess, 30, 23-24). Within the same category of non-prototypical nouns we can include collective nouns such as fêliu 'trib, seminție, neam', explained by Arvinte (1997, p. 39) through the formal proximity set by Nicolae Milescu between the Greek word ( $) \varphi v \lambda \dot{\eta},-\eta \dot{\eta} \varsigma$ or Gr. $(\tau \dot{j}) \varphi v \lambda \circ v$, -ov and the Romanian word fel, to whom he assigned that meaning: caută fêliul lui Levi să nu-l socotești împreună (Num, 1, 49), ficiorul lui Aminadav, boiêrin a fêliului Iudei (Num, 7, 12), veți da moștneniirea rudeniei celui aproape lui den fêliul lui (Num, 27, 11), adunai cătră mine pre mai marii fêliului vostru (Deut, 31, 28), viță 'tribe, family, nation': după casele vițelor lor (Num, 1, 2), or bătrînime ('council of elders', 'all the elders'): chemă Moisi toată bătrînimea lui Israil și dzise cătră înșii (Ieș, 12, 21), vor trimite bătrînimea cetăției lui (Deut, 19, 12), etc.

4.1.2. Also, the several periphrastic verbal constructions of the text have been related to the Greek influence; Vasile Arvinte exposes in detail, especially in his 1993 study, the periphrastic moods and tenses calqued from Greek that went from ms. 45 to the Bible of Bucharest. Some periphrastic forms contain the auxiliary a fi and the gerundive of the main verb; such forms are those of periphrastic present: $\boldsymbol{n u}$ sint știind a grăi jidovêște (Neem, 13, 24); periphrastic imperfect: Avenir era țiind casa lui Saul $(2$ Reg, 3, 6), periphrastic perfect: și funăscîndu ea $(F a c, 38,28)$ or periphrastic future: și 5 gardurivorfițiindu-săunul de la alalt (Ieș, 26, 3). Periphrastic forms with other structures such as, for example, the one composed of the verb vrea + the infinitive of the main verb have also been identified (Arvinte, 1991, p. 22): cindu vrea mêrge Moisi înaintea Domnului să-i grăiască lui, lua acoperemîntul pînă ce ieșiia (Ieș, 34, 34; in the Greek

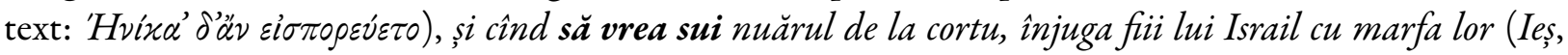
40, 33; in the Greek text: 'Hvix $\left.\delta^{\prime}{ }^{\prime \prime} \nu \dot{\alpha} \nu \varepsilon \hat{\beta} \iota \dot{\eta} \nu \varepsilon \varphi \varepsilon \dot{z} \eta\right)$ ); another periphrastic form of perfect highlighted by Arvinte (1994, p. 11) contains the verb a se face + the gerund of the main verb (representing a means to

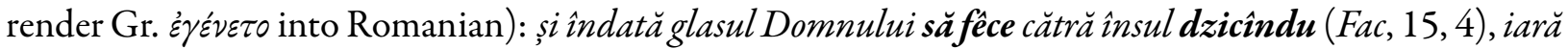
dimineața să fêce potolindu-să roao pregiur tabără (Ieș, 16, 13), norul Domnului să fêce umbrindu preste ei $d z u a$ (Num, 10, 34). Also, another two ways of exposing the future, calqued from Greek, are mentioned by Arvinte (1994, p. 12): one consists of the future form of the verb a f, followed by the adverb cind + the 


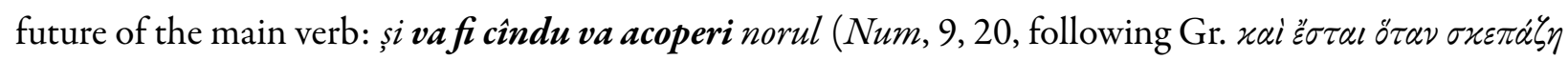
$\dot{\eta} \nu \varepsilon \varphi \varepsilon \dot{\varepsilon} \lambda)$; the second consists of the future of the verb a fi, followed by the conjunction $d e+$ the future

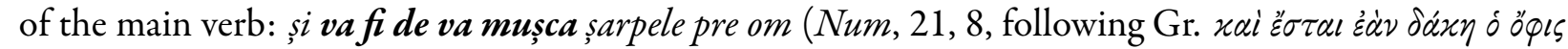
$\ddot{\alpha} \nu \vartheta \rho \omega \pi \circ \nu)$, etc.

In addition to the periphrastic forms recorded in the cited studies, we identified a periphrastic form of the gerund, made of the auxiliary verb a $f i$ in the gerund + main verb in the participle: și să spuse lui Saul, dzicîndu căci nărodul au greșit Domnului, mîncat fiind cu sîngele (mîncat fiind = 'mîncînd' [eating]) (1Reg, 14, 33), a multe limbi domnindșifind biruit toată lumea (fiind biruit = 'biruind' [defeating]) (Est, 3, 13), o, ticăloasa eu, și de multe ori de trei ori mișa, carea 7 copii fiind născută, a nici unuia maică m-am făcut (fiind născută = 'născînd' [ giving birth]) (Iosip, 16, 6).

4.1.3. Other phenomena have also been explained on account of the Greek influence: the lack of the definite article lui before some proper names: ficior Amisadai (Num, 1, 12), fiu Enan (Num, 1, 15), etc.; the occasional use of uninflected feminine names ending in a consonant: in casa Rabil (Fac, 31, 34); keeping the Greek ending of the genitive for the proper names: ficiorul ii Melhas (Fac, 24, 15); some changes in declension, such as the form of the $2^{\text {nd }}$ declension brățariu: și cercel, și inel, și brățariu (Num, 31, 50); the repetition of the adverb foarte for the superlative of adjectives and adverbs: piatra - multă foarte, foarte (Ies, 9, 24); the use of syntagms such as om carele and om om with an indefinite pronoun value, having the meaning of 'everyone, anyone, someone'; the enrichment of some adjectives, through semantic loan translation, with meanings taken from Greek (the meaning înalt' of the adjective long, the meaning 'strong' of the adjective inalt, and so on); the use of some infinitive constructions, namely of the so-called intensive constructions made of the gerund and another form of the same verb: stiindu vei ști (Fac, 15, 13), putînd va putea cătră noi (1Mac, 5, 40), închizîndu închise Dumnedzău (Fac, 20, 18), vădzîndu-te am vădzut (Fac, 26, 28), putînd au putut (2Paral, 32, 13), puind să pui preste sine boiêrin (Deut, 17, 15), etc.

In the category of elements specific to the text itself we can also add several other language facts:

\subsection{Demonstrative pronouns}

In ms. 45 , unaşi is used with the same value as the demonstrative pronoun of identity aceeași: celor ce calcă preste țărna pămîntului $\mid$ și da palme la capetile săracilor și calea smeriților au abătut și fu și tatăl lui mergea cătră unaşi slujnică, pentru ca să pîngărească numele Dumnedzăului lor (Am, 2, 7), nu știți că unul pre mine cu cei morți m-au sămănat tată și unași maică m-au născut și pre unele ne-am hrănit porînci? (Iosip, 10, 2), întru unași vrême zidindu-ne și de la un sînge crescîndu-ne și pren un suflet săvîrșindu-ne (Iosip, 13, 20).

\subsection{Reciprocal voice}

In the reciprocal voice, after the morpheme $s e+$ verb (in plural), the complement of reciprocity inde sine follows (expressed by the reflexive pronoun sine preceded by the preposition inde), having the value 'one another', 'among them', etc.: săracul și bogatul s-au tîmpinat înde sine (Parim, 22, 2), și Ioav, ficiorul Saruiei, și slugele David au ieșit den Hevron și să tîmpinară înde sine (2Reg, 2, 13), țîncii leilor s-aupărăsit înde sine (Iov, 4, 11), și s-au lovit înde sine și au căzut dentru tabăra Lisiei ca vro 5000 de oameni (1Mac, 4, 34), îndemnară-să înde sine, zicînd (Iosip, 13, 8), înde sine împreună toți căutîndu-să (Iosip, 13, 13).

In only one case, the complement of reciprocity is expressed by the pronoun eiși $(e i+s, i)$ preceded by the preposition adinsu 'between': să preasăruta adinsu eiși (3Mac, 5, 49).

\subsection{Conjunctions}

4.4.1. The strongest form of the adversative relation is achieved both by ce (with its newer variant $c i$ ) and by the conjunction fară 'but' followed by the adverb numai ${ }^{7}$ : și lui Salpad, fiul lui Ofer, nu i s-au fäcut lui ficiori, färă numai fête (= 'but only girls') (Num, 26, 33), voi ați audzit și asămănare n-ați vădzut, fără

\footnotetext{
${ }^{7}$ For the use of fără (numa) as a mark of adversative coordination in Northern Transylvania, see Botoșineanu (2007, p. 212).
} 
numai glas (Deut, 4, 12), și nu la părinții voștri au făgăduit Domnul făgăduința aceasta, fără numai cătră voi (Deut, 5, 3), toate cetățile cêle tari nu le-au arsu Israil, färă numai pre Assor sîngură au arsu-o Iisus (Ios, 11, 13), și nu iaste altul scutind limbei Israil, färă numai tu (Idt, 9, 14).

4.4.2. The conjunctions iară and insă occur also with the value of concessional adverbs 'totuși, tot', in regent sentences of some concessional subordinates introduced by the conjunction de, meaning 'chiar dacă: de va uita și acêstea muiêrea, iară eu nu voi uita pre tine, dzice Domnul (= 'chiar dacă va uita..., eu tot nu voi uita pre tine') $(I s, 49,15)$, dă vei bate pre cel fără minte, în mijlocul adunării necinstindu-l, însă nu vei lua nebuniia lui (= 'chiar dacă vei bate pre cel fără minte...., tot nu vei lua nebuniia lui') (Parim, 27, 22).

\subsection{Super-compound conditional}

A super-compound form of conditional of the type that represents "genuine forms of past perfect conditional", with four verbal elements, which "expresses a more pronounced rebound in the past" (Frâncu, 1983-1984, p. 35), occurs only once: vrut-am fi murit în pămîntul Eghiptului, au întru pustiiul acesta să am fi murit! (Num, 14, 3).

\section{Conclusions}

The diachronic analysis combined with the synchronous one, applied to the lexical and grammatical classes, proves the diversity of language facts recorded in ms. 45. Beside the permanent points that have been preserved over time, thus ensuring the continuity of the morphological system, we can find a number of innovations, of changes (regarding the declension, conjugation or categories of gender, number, case, tense, mode, voice), either in the early or advanced stages, as well as a number of elements specific to the text as such. If, generally, the morphological changes follow two trends, that of simplification and that of development / redundancy (Frâncu, 2009, p. 17), then simplifying the nominal inflection through modifying the genitive-dative of the feminine nouns, of the flectives formed of a desinence $(-e$ or $-i)$ and a definite article $(-e i)$ (the flectives $-e e i$ and $-i e i>-e i$ and $-i i$ ) is included in the first category, while marking the opposition number, in addition to the ending by phonetical alternation, enters the second category. Some of the changes highlighted in this analysis confirm several inter-conditionings reported in the literature; such is the case, for instance, of the masculine - neutral and neutral - feminine changes, coupled with the imposition of plural and singular forms, respectively, or of the morphological repercussions of some phonetic changes.

\section{Bibliography}

Arvinte, V. (1988). Studiu lingvistic asupra primei cărți (Facerea) din Biblia de la București (1688), în comparație cu Ms. 45 și cu Ms. 4389, in Monumenta Lingux Dacoromanorum. Biblia 1688, Pars I. Genesis, Editura Universității "Alexandru Ioan Cuza”, Iași, p. 47-105.

Arvinte, V. (1991). Studiu lingvistic asupra cărții a doua (Ieșirea) din Biblia de la București (1688), în comparație cu Ms. 45 și cu Ms. 4389, in Monumenta Lingux Dacoromanorum. Biblia 1688, Pars II. Exodus, Editura Universității "Alexandru Ioan Cuza”, Iași, p. 1-51.

Arvinte, V. (1993). Studiu lingvistic asupra cărții a treia (Preoția) din Biblia de la București (1688), în comparație cu Ms. 45 și cu Ms. 4389, in Monumenta Lingux Dacoromanorum. Biblia 1688, Pars III. Leviticus, Editura Universității "Alexandru Ioan Cuza”, Iași, p. 1-41.

Arvinte, V. (1994). Studiu lingvistic asupra cărții a patra (Numerii) din Biblia de la București (1688), în comparație cu Ms. 45 și cu Ms. 4389, in Monumenta Lingue Dacoromanorum. Biblia 1688, Pars IV. Numeri, Editura Universității "Alexandru Ioan Cuza”, Iași, p. 1-44.

Arvinte, V. (1997). Studiu lingvistic asupra cărții a cincea (A doua lege) din Biblia de la București (1688), în comparație cu Ms. 45 și cu Ms. 4389, in Monumenta Lingue Dacoromanorum. Biblia 1688, Pars V. Deuteronomium, Editura Universității "Alexandru Ioan Cuza", Iași, p. 1-69.

Botoşineanu, L. (2007). Graiul de pe valea superioară a Someşului Mare, Editura Alfa, Iași.

Densusianu, Ov. (1932). Histoire de la langue roumaine, vol. II, Librairie Ernest Leroux, Paris.

Diaconescu, P. (1970). Structură și evoluție în morfologia substantivului românesc, Editura Academiei, București. 
Dimitrescu, F. (coord.) (1978). Istoria limbii române. Fonetică. Morfostintaxă. Lexic, Editura Didactică și Pedagogică, București. Frâncu, C. (1967). Din istoria perfectului simplu românesc: formele de persoana I și a II-a plural cu sufixul -ră, in "Anuar de lingvistică și istorie literară”, tome XVIII, p. 175-192.

Frâncu, C. (1969). Formele de persoana a III-a ale auxiliarului de la perfectul compus. Privire istorică, in "Studii și cercetări lingvistice", vol. XX, no. 3, p. 299-318.

Frâncu, C. (1980). Din istoria verbelor neregulate: perfectul simplu și mai mult ca perfectul verbelor a da și a sta, in "Limba română”, vol. XXIX, no. 4, p. 307-316.

Frâncu, C. (1983-1984). Geneza și evoluția formelor verbale supracompuse în limba română, in "Anuar de lingvistică și istorie literară", tome XXIX, p. 23-62.

Frâncu, Constantin (2000). Conjunctivul românesc și raporturile lui cu alte moduri, Casa Editorială Demiurg, Iași.

Frâncu, Constantin (2009). Gramatica limbii române vechi (1521-1780), Casa Editorială Demiurg, Iași.

GALR = Gramatica limbii române, vol. I. Cuvîntul, Editura Academiei Române, București, 2005.

Gheție, I. (1973). Originea auxiliarului a de la pers. 3 sg. a perfectului compus, in “Studii și cercetări lingvistice”, vol. XXIV, no. 4, p. $421-430$.

Gheție, I. (1975). Baza dialectală a limbii române, Editura Academiei, București.

Gheție, I. (coord.) (1997). Istoria limbii române literare. Epoca veche (1532-1780), Editura Academiei Române, București.

Gheție, I. \& Mareș, Al. (1974). Graiurile dacoromâne în secolul al XVI-lea, Editura Academiei, București.

Guțu Romalo, V. (1965). Din morfologia sec. al XVI-lea : perfectul simplu al verbului a face, in Omagiu lui Al. Rosetti la 70 de ani, București, p. 337-540.

Sădeanu, F. (1959). Traces de passé composé absolu en roumain, in Recueil d'études romanes, publié à l'occasion du IXe Congrès international de linguistique romane à Lisbonne du 31 mars au 3 avril 1959, București, p. 315-320.

Vasiliu, Em. (1968). Fonologia istorică a dialectelor daco-române, Editura Academiei, București. 